\title{
Isolated Inguinal Lymph Node Metastasis in Patient with Lung Cancer
}

\section{Akciğer Kanserli Olguda İzole İnguinal Lenf Nodu Metastazı}

\author{
Yasemin Benderli Cihan ${ }^{1}$, Dilek Ünal ${ }^{1}$, Ümmügülsüm Gümüşs \\ ${ }^{1}$ Kayseri Eğitim Ve Araştırma Hastanesi, Radyasyon Onkoloji, Kayseri, Türkiye \\ ${ }^{2}$ Kayseri Eğitim Ve Araştırma Hastanesi, Radyoloji, Kayseri, Türkiye
}

Doi: $10.5505 /$ aot.2012.64936

Anahtar Kelimeler: Akciğer kanseri; İnguinal metastaz; Lenf nodu

Key words: Lung cancer; Inguinal metastasis; Lymph node

\section{Sayın Editör;}

Genital ve üriner sistem tümörlerinde, diyafram altı tümörlerde, inguinal lenf nodu metastazı sık görülmektedir (1). Akciğer kanserinde inguinal lenf nodu metastazlarına nadiren rastlanır (2).

Altmışaltı yaşında erkek hasta sol omuzda ağrı şikâyeti ile kliniğimize başvurdu. Akciğer grafisinde sol akciğer üst lobta opasite saptanması üzerine çekilen toraks bilgisayarlı tomografisinde (BT) sol üst lob apikoposterior segmentte ve sol paratrekeal ve subkarinal bölgede patolojik boyutta lenf nodu belirlendi. Bronkoskopik biyopsi sonucu epidermoid kanser olarak rapor edildi. Lokal ileri evre kabul edilen hastaya neoadjuvan sisplatin+ dosetaksel 6 kür uygulandı. Kemoterapi sonras1 yapılan tetkiklerinde regresyon saptanan hastaya segmentektomi sonras1 postoperatif olarak $60 \mathrm{~Gy} / 30 \mathrm{fr}$ radyoterapi uyguland 1 ve takibe alınd. Tanıdan 3 ay sonra, olgu sağ kasık bölgesinde şişlik ve ağrı yakınmalarıyla kliniğimize başvurdu. Fizik muayenede sağ inguinal bölgede $5 \times 4 \mathrm{~cm}$ boyutlarında sert fikse lenf nodları belirlendi. Sol inguinal, aksiller ve supraklaviküler lenf nodları klinik olarak negatifti. Pelvik BT tetkikinde sağ inguinal bölgede yaklaşı $6 \mathrm{~cm}$ çaplı yumuşak doku dansitesinde konglomere LAP paketine ait görünüm izlendi (Resim 1).

Lezyondan alınan biyopsinin patolojik incelenmesinde karsinom metastazı olarak rapor edildi. Bu bölgeye palyasyon amaçli 36 Gy/12 fraksiyon radyoterapi uyguland 1 ve tekrar kemoterapi planlandı. Olgu hastalık progresyonu nedeniyle 3 ay sonra kaybedildi. Sonuç olarak akciğer kanser nadirde olsa inguinal bölgede lenf nodlarına da metastaz yapabilmektedir. Ayrıca bu olgu ilk nüks yeri olarak inguinal bölgenin olması nedeniyle de özellikli idi.

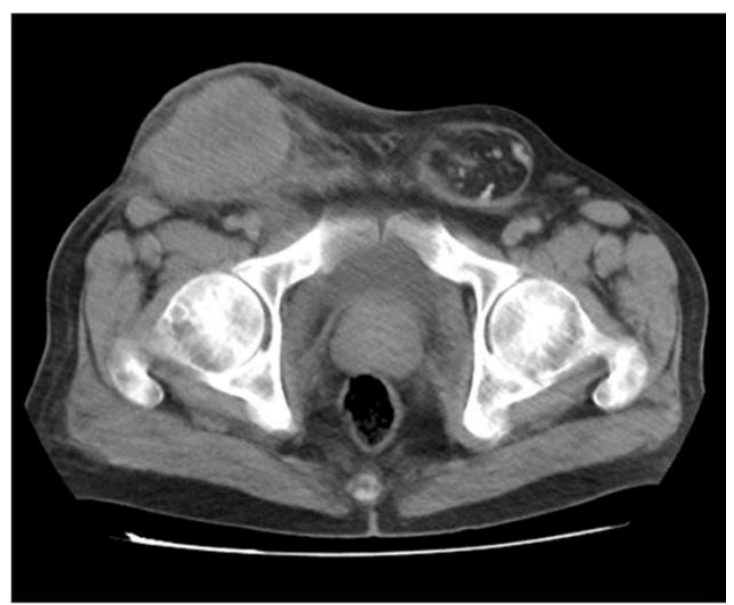

Resim 1: Kontrastsız aksiyal pelvik BT tetkikinde sağ inguinal bölgede yaklaşık $6 \mathrm{~cm}$ çaplı yumuşak doku dansitesindeki konglomere LAP paketine ait görünüm izlenmekte

\section{Çıkar Çatışması: Yok}

\section{Kaynaklar}

1. Ang D, Ng KY, Tan HK, Chung AY, Yew BS, Les VK. Ovarian carcinoma presenting with isolated contralateral inguinal lymph node metastasis: a case report. Ann Acad Med Singapore 2007;36:427-30

2. Ahmet Emin E, Eser G, Fevziye T, Salih G, Seyit M. İnguinal Lenf Bezi ve Cilt Metastazı (Carcinoma Erysipelatoides) ile Seyreden Akciğer Kanseri (Olgu Sunumu). Solunum Hastalıkları 2006;17:34-7 